\title{
NEU1 and NEU3 enzymes alter CD22 organization on B cells
}

\author{
Hanh-Thuc Ton Tran, Caishun Li, Radhika Chakraberty, Christopher W. Cairo*
}

Department of Chemistry, University of Alberta, Edmonton Alberta, T6G 2G2, Canada

*To whom correspondence should be addressed. Tel.: 780492 0377; fax: 780492 8231; email: $\underline{\text { ccairo@ualberta.ca }}$ 


\section{ABSTRACT}

The B cell membrane expresses sialic acid binding Immunoglobulin-like lectins, also called Siglecs, that are important for modulating immune response. Siglecs have interactions with sialoglycoproteins found on the same membrane (cis ligands) that result in homotypic and heterotypic receptor clusters. The regulation and organization of these clusters, and their effect on cell activation, is not clearly understood. We investigated the role of human neuraminidase enzymes, NEU1 and NEU3, on the clustering of CD22 on B cells using confocal microscopy. We observed that native NEU1 and NEU3 activity influence the cluster size of CD22. Using singleparticle tracking, we observed that NEU3 activity increased the lateral mobility of CD22, which was in contrast to the effect of exogenous bacterial NEU enzymes. Moreover, we show that native NEU1 and NEU3 activity influenced cellular $\mathrm{Ca}^{2+}$ levels, supporting a role for these enzymes in regulating B cell activation. Our results establish a role for native NEU activity in modulating CD22 organization and function on B cells. 


\section{INTRODUCTION}

$\mathrm{B}$ cell receptors (BCRs) are responsible for antigen recognition leading to B cell activation and proliferation in immune response. Regulation of B cell activation involves co-receptors that fine-tune BCR signaling. One widely studied negative regulator of BCR is CD22 (Siglec-2), a member of the sialic-acid binding Immunoglobulin-like lectin (Siglec) family.(1) The structure and organization of CD22 on the cell membrane plays a crucial role in its activity. CD22 is a transmembrane protein containing seven Immunoglobulin domains (Ig) that adopts a rod-like structure; the N-terminal Ig domain specifically recognizes terminal $\alpha 2,6$-sialic acids.(2) The cytoplasmic portion of CD22 contains Immunoreceptor Tyrosine Inhibitory Motifs (ITIMs) that dampen cellular response.(3) CD22's lectin domain can interact with sialosides from cis- or transligands; however, the high density of cis sialosides on the membrane results in the formation of hetero- and homotypic clusters of CD22. The N-link glycans of CD22 allow for homotypic interactions, $(4,5)$ while heterotypic cis-binding partners, including CD45,(6,7) are known. Although CD22's ligand binding is somewhat weak,(8) high-affinity trans-ligands can overcome cis-interactions despite their prevalence. $(9,10)$ High-affinity multivalent displays of CD22 ligands including liposomes, $(11,12)$ polymers, $(4,10,13)$ and synthetic scaffolds $(14)$ have been proposed as modulators of B cell activation.

The complexity of CD22 interactions and organization on the B cell membrane remains an active area of investigation. Previous studies have observed nanoclusters of CD22, with a minor role for the actin cytoskeleton in lateral mobility.(15) Despite the large number of sialylated glycoproteins on the membrane, only a limited number of these have been identified as in situ CD22 ligands.(5) This observation may indicate a role for membrane microdomains in enforcing specific interactions, as CD45 and IgM have close associations with lipid rafts.(16-19) A common 
strategy for investigating the role of CD22-sialoside interactions is to use sialic acid-cleaving enzymes: neuraminidases (NEUs, also called sialidases).(20) Recombinant NEU from bacteria have been used for this purpose as research tools. NEU from Clostridium perfringens (NanI) has substrate preference for $\alpha 2,3-$ glycoproteins, while the sialidase of Athrobacter ureafaciens (siaAU) has a broader range of substrate specificity cleaving $\alpha 2,3-, \alpha 2,6-$, or $\alpha 2,8$-linked gangliosides or glycoproteins. Exogenous NEU reagents have helped establish the importance of CD22-sialoside interactions; however, there has been very little work to investigate the role of native NEU enzymes on this system. There are four human NEU isoenzymes (hNEU): NEU1, NEU2, NEU3, and NEU4 and they have important cellular functions and roles in health and disease,(21) including atherosclerosis,(22) malignancy,(23-25) and neurodegenerative diseases.(26-29) Together with glycosyl transferase enzymes (GTs), NEU regulate sialic acid content in cells.(20) Thus, native NEU activity could act as a regulator of CD22 organization, B cell activation, and immune response.

Here, we investigated the influence of the cytoskeleton and native NEU activity on the membrane organization and dynamics of CD22. By utilizing confocal microscopy and singleparticle tracking, we found that clustering and diffusion of these receptors are dependant on both cytoskeletal structure and changes in glycosylation of B cells. We confirmed our findings by performing knockdown of hNEU expression in model B cells. Finally, we confirmed that native hNEU activity affects B cell calcium levels. We conclude that organization and diffusion of CD22 receptors is dependent on an intact cytoskeleton and the homeostasis of native sialoside ligands. 


\section{MATERIALS AND METHODS}

\section{Confocal microscopy}

Cells were grown in R10 media and kept in a humidified incubator at $37^{\circ} \mathrm{C}$ and $5 \% \mathrm{CO}_{2}$. For confocal microscopy experiments, Raji cells $\left(1 \times 10^{6}\right)$ were counted, centrifuged, and resuspended in Hank's Balanced Salt Solution (HBSS). The cells were washed and treated with NanI (Clostridium perfringens), siaAU (Athrobacter ureafaciens), or NEU3 in HBSS, or CytoD or LatA in HBSS with $0.005 \%$ DMSO at $37^{\circ} \mathrm{C}$ for 1 hour, then fixed using $1 \%$ PFA on ice for $30 \mathrm{~min}$. Samples were treated with $1 \mu \mathrm{L} / \mathrm{mL}$ mouse anti-human IgM (clone IM260, Abcam cat\# ab200541) or mouse anti-human CD22 (clone HIB22, BD Pharmingen cat\# 555423) at $4{ }^{\circ} \mathrm{C}$ overnight, and stained with goat anti-mouse IgG (polyclonal, Sigma-Aldrich cat\# M8642) conjugated with Alexa Flour 647 (AF647) at room temperature for $1 \mathrm{~h}$. The loading of the fluorophores was approximately 2 dyes/protein. After washing, samples were transferred to 24-well plates (Corning, Inc.) with circular cover glass slides pre-treated with poly-L-lysine (PLL), spun at $300 \mathrm{x}$ g for $15 \mathrm{~min}$, washed, and glass slides were mounted onto microscopy slides with Slowfade Antifade (Thermo Fisher, cat\# S2828) and sealed using Cytoseal 60. Samples were imaged on a laser scanning confocal microscope (Olympus IX81 with 60X objectives). Twenty cells from each condition were chosen for analysis based on transmitted and fluorescence images, and each cluster was analyzed using the particle analysis function on ImageJ. The data were plotted using the beanplot plugin in $\mathrm{R}$, and statistics were done using Graphpad Prism. Three runs were performed and analyzed, and one representative run is shown for each condition.

\section{Single-Particle Tracking}

Raji cells were grown in R10 media as previously described.(14) For each condition, cells $\left(1 \times 10^{6}\right)$ were counted and washed with HBSS buffer three times. The cells were then re- 
suspended in HBSS and treated with NanI $(10 \mathrm{mU} / \mathrm{mL})$, siaAU $(5 \mathrm{mU} / \mathrm{mL}$ or $10 \mathrm{mU} / \mathrm{mL})$, or NEU3 $(10 \mathrm{mU} / \mathrm{mL})$. For CytoD and LatA, the cells were re-suspended in $0.005 \%$ DMSO and the compounds were added to a final concentration of $100 \mathrm{mM}$. For all conditions, the cells were incubated for $1 \mathrm{~h}$ at $37{ }^{\circ} \mathrm{C}$ and $5 \% \mathrm{CO}_{2}$. After incubation, the cells were centrifuged and washed three times with HBSS buffer at $200 \mathrm{x}$ g for $15 \mathrm{~min}$, re-suspended in HBSS and labelled with antiCD22 conjugated with AF647 (1h at room temperature). After labelling, the cells were washed three times in buffer then transferred to 24 well-plates with circular glass cover pre-treated with PLL. The plate was then spun at $300 \mathrm{x}$ g for $15 \mathrm{~min}$, and the cover glass was mounted to microscope slides with buffer and sealed with Cytoseal 60. To record the trajectories, TIRFM was performed on Nikon Ti microscope. The angle of incidence was set at $\sim 1100$, and videos were taken at 10 FPS for 10 seconds.(30) All the videos were taken within one hour of slide preparation. Trajectories were analyzed using UTrack software in MATLAB, and the coefficient of diffusion was calculated using MATLAB.(30)

\section{Transfection of Raji cells}

Raji cells were grown as described and passaged $24 \mathrm{~h}$ prior to transfection.(14) Cells (24 x $10^{6}$ ) were washed and re-suspended into $750 \mu \mathrm{L}$ of electroporation buffer (PBS with no $\mathrm{Ca}^{2+}$ or $\mathrm{Mg}^{2+}$ ). For each knock-down condition, $15 \mu \mathrm{L}$ from the $20 \mu \mathrm{M}$ stock siRNA solution was added, while $15 \mu \mathrm{L}$ of siRNA buffer was added for the no-treatment control. Cells were mixed by pipet and transferred to a $2 \mathrm{~mm}$ electroporation cuvette. Cell samples were left on ice for $20 \mathrm{~min}$, and electric shock was applied using a Bio-Rad electroporator $(0.6 \mathrm{kV}, 50 \mu \mathrm{F}$, and $350 \Omega)$. The cuvettes were then immediately transferred and left on ice for $30 \mathrm{~min}$. Transfected cells were transferred to T25 cell culture flasks and pre-warmed R10 growth medium was added so the final volume for 
each condition was $6 \mathrm{~mL}$. Cells were kept in a humidified incubator at $37^{\circ} \mathrm{C}$ with $5 \% \mathrm{CO}_{2}$ for 24

h.

\section{$\mathrm{Ca}^{2+}$ activity assay of Raji cells}

For each condition, Raji cells were counted and re-suspended to a final concentration of $1 \mathrm{x}$ $10^{6}$ cells $/ \mathrm{mL}$. Cells were then treated with NEU at a final concentration of $10 \mathrm{mU} / \mathrm{mL}$ or with 100 $\mathrm{nM}$ neuraminidase inhibitors. For treatments of enzyme with inhibitors, these were incubated together for $30 \mathrm{~min}$ before addition to cells. The cells were treated with indicated conditions for 1 h at $37{ }^{\circ} \mathrm{C}$ with $5 \% \mathrm{CO}_{2}$. For transfected cells, cells were transfected and grown 24 hours prior to $\mathrm{Ca}^{2+}$ experiments. Cells were washed three times with PBS and re-suspended at $5 \times 10^{6} / \mathrm{mL}$ in loading buffer (RPMI-1640 supplemented with 1\% FBS, $10 \mathrm{mM}$ HEPES, $1 \mathrm{mM} \mathrm{MgCl} 2,1 \mathrm{mM}$ EGTA, and 5\% penicillin-streptomycin) and treated with $1.5 \mu \mathrm{M}$ Indo-1 dye in a $37^{\circ} \mathrm{C}$ water bath for 30 min while protected from light. After loading, the cells were washed with loading buffer three times, then re-suspended in running buffer (HBSS supplemented with $1 \% \mathrm{FCS}, 1 \mathrm{mM}$ $\mathrm{MgCl}_{2}$ and $1 \mathrm{mM} \mathrm{CaCl}$ ), after which they were stored on ice. Using a Fortessa X10 FACS machine, a plot of violet $(379 \mathrm{~nm})$ versus blue $(450 \mathrm{~nm})$ was created and voltages were adjusted so that a maximum of $5 \%$ of unstimulated cells lie within the violet gate. To measure the amount of $\mathrm{Ca}^{2+}$ flow into the cells, $500 \mu \mathrm{L}$ of previously suspended cells from each condition were transferred to FACS tubes incubated in $37^{\circ} \mathrm{C}$ water bath for $2 \mathrm{~min}$ before running the samples. Ten seconds after the acquisition was initiated to establish the background, the tube was quickly removed and either PBS (unstimulated condition) or anti-IgM (stimulated condition) was added and vortexed before placing the tube back. The total acquisition time was 3 min for each tube and the number of cells analyzed ranged from 150-400 thousand cells. From these data, the percentage 
of cells emitting violet light from each condition was normalized to that of control unstimulated cells, and a Student's t-test was performed with GraphPad Prism.

\section{Western Blot of Raji cells}

Transfected cells were centrifuged and supernatant was discarded. The cells were lysed using $100 \mu \mathrm{L}$ of HEPA buffer with protease inhibitor on ice for $1 \mathrm{~h}$. The lysate was sonicated and centrifuged at $12000 \times \mathrm{g}$ for $20 \mathrm{~min}$. Supernatant was collected and the amount of protein was determined using BCA assay. For each condition, $10 \mu \mathrm{g}$ of protein was mixed with the same volume of $2 \mathrm{X}$ gel running buffer with $5 \%$ dithiothreitol, followed by 5 min incubation at $95{ }^{\circ} \mathrm{C}$. After heating the samples, they were then transferred to $11 \%$ acrylamide gel and SDS-PAGE was run at $110 \mathrm{~V}$ for $70 \mathrm{~min}$. After the gel was completed, it was washed with water, and transferred to a nitrocellulose membrane in $1 \mathrm{X}$ blotting buffer at $20 \mathrm{~V}$ for $2.5 \mathrm{~h}$. Once the transfer was completed, the transfer of proteins was confirmed by soaking the membrane in Ponceau S buffer for $5 \mathrm{~min}$, washing the membrane with water, and checking for presence of bands on the membrane. The membrane was blocked in blocking buffer (5\% non-fat milk in 1X TBST) on an orbital shaker overnight at $4{ }^{\circ} \mathrm{C}$. The membrane was then washed three times with TBST for 5 min each time. The membrane was stained using primary antibody in TBST with 1:1000 dilution for 1 $\mathrm{h}$ at room temperature. The membrane was washed 5 times with TBST, then stained using secondary antibody conjugated with horse radish peroxidase with 1:10000 dilution in TBST for 1 $\mathrm{h}$ at room temperature. The membrane was washed and developed using ECL substrate for western blotting and visualized. Percent knock-down was determined by analyzing the intensity of each band using ImageJ. The samples were normalized to the control, and a Student's t-test was implemented for analysis.

\section{Lectin blots}


CD22 proteins were purified from Raji cells using murine hybridoma cells expressing antiCD22 antibodies ( $\alpha$-CD22:4213 (10F4.4.1)). The purified sample was validated by SDS-PAGE and the protein concentration were determined using a BCA assay. From the stock solution, 4.4 $\mu \mathrm{g}$ of protein was diluted to a final volume of $200 \mu \mathrm{L}$ and enzyme concentration of $10 \mathrm{mU} / \mathrm{mL}$, then the samples were incubated at $37^{\circ} \mathrm{C}$ for 3 hours. After treatment of the proteins with enzyme, each sample was mixed with the same volume of $2 X$ PAGE sample buffer with SDS, then $40 \mu \mathrm{L}$ from each sample was subjected to SDS-PAGE with $10 \%$ acrylamide at $110 \mathrm{~V}$ for 70 minutes. For each of the samples, three lanes were loaded together with control samples. Gels were then taken out, washed three times with water, and transferred to nitrocellulose membrane. The presence of proteins on the membrane was confirmed using Ponceau S, then they were cut so that a control and an enzyme-treated lane was retained. The membranes were washed with TBST and blocked with blocking buffer ( $5 \%$ non-fat milk in TBST) at $4{ }^{\circ} \mathrm{C}$ overnight. Membranes were washed three times with TBST, then treated with $1 \mu \mathrm{g} / \mathrm{mL}$ biotinylated lectins (PNA, SNA, MAL) at room temperature for $1 \mathrm{~h}$. The treated membranes were washed 5 times with TBST and treated with streptavidin-HRP for $1 \mathrm{~h}$ at 1:10000 dilution, followed by washing the membranes with TBST. The bands were detected using ECL substrate for western blotting under a visualizer. The analysis of the bands was conducted using ImageJ. 


\section{RESULTS}

\section{Cytoskeletal interactions of BCR}

To study the effect of cytoskeletal contacts on BCR, we used Raji cells treated with cytoskeletal disruptors cytochalasin D (CytoD) and latrunculin A (LatA) as a model B cell system. Microclusters of BCR are known to form when B cells are stimulated due to the association of the constant region $\mathrm{C} \mu 4$, followed by phosphorylation that induces cellular response.(31) Several studies have observed cytoskeletal interactions with BCR, and the effect of cytoskeletal disruption was increased BCR cluster size and cell activation. $(32,33)$ Cells were treated, fixed, and imaged by confocal microscopy allowing quantitation of cluster size (Figure 1).(14) CytoD and LatA were used to disrupt the cytoskeleton.(34-37) We observed a significant increase in clustering of BCR upon treatment with both inhibitors at all concentrations,(15) and there was significantly increased clustering at lower concentration as compared to higher concentrations $(2.5$ vs $7.5 \mu \mathrm{g} / \mathrm{mL} ; \mathrm{p}<$ 0.05).(38)

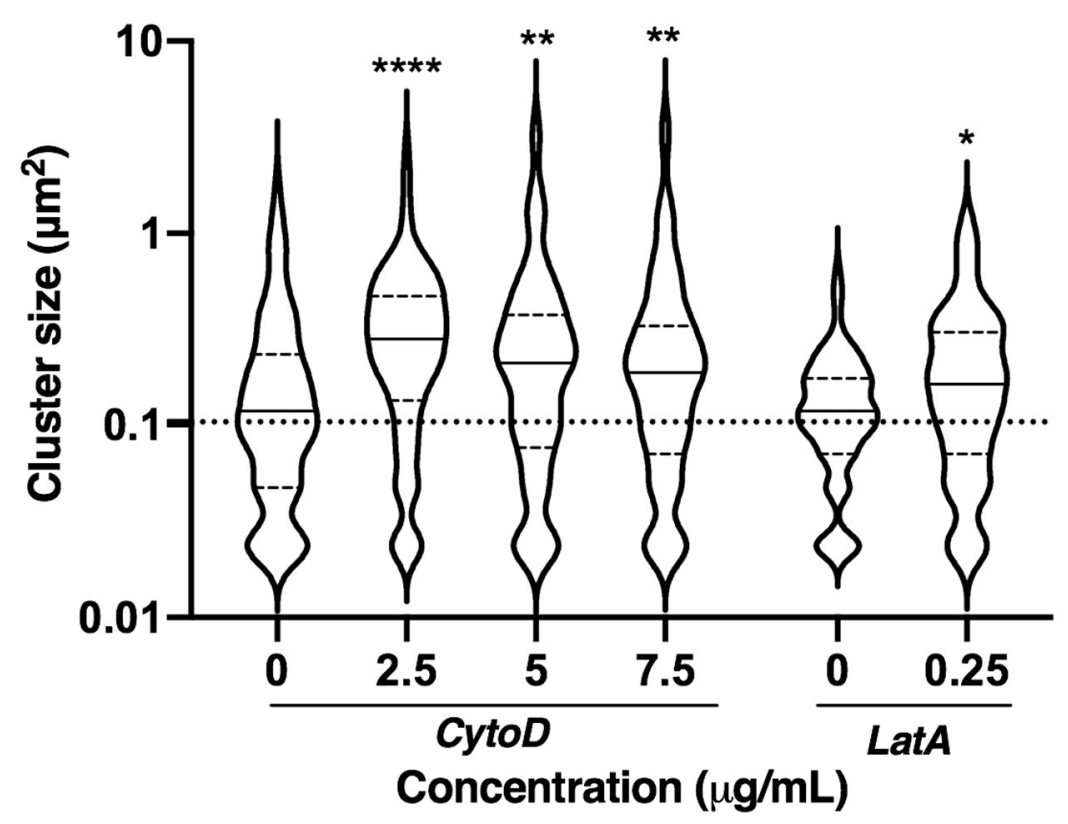


Figure 1. Cluster size of BCR after treatment with cytoskeletal disruptors. Raji cells were treated with cytochalasin D (CytoD) or latrunculin A (LatA) at $37{ }^{\circ} \mathrm{C}$ for $30 \mathrm{~min}$. Cells were then fixed and stained with mouse anti-IgM and anti-mouse IgG-AF647 and imaged using confocal microscopy. Data shown are average from 30 cells among 3 biological replicates; cells were analyzed using imageJ and shown as beanplots.(14) Comparisons by student's t-test are shown relative to respective controls $(* * * *, \mathrm{p}<0.0001 ; * *, \mathrm{p}<0.01 ; *, \mathrm{p}<0.05)$.

\section{Cytoskeletal interactions of CD22}

We next examined the cytoskeletal interactions of CD22 in a B cell model. Analysis of CD22 clustering after treatment with cytoskeletal disruptors is shown in Figure 2. We observed that CD22 cluster size increased significantly when cells were treated with CytoD. Interestingly, the cluster size was increased at intermediate concentrations $(2.5-7.5 \mu \mathrm{g} / \mathrm{mL})$; however, this effect was lost at higher concentration $(10 \mu \mathrm{g} / \mathrm{mL})$. Similar trends have been observed in tight junctions, and may be attributed to different populations of actin within the cell. $(38,39)$ Previous work has suggested that CytoD does not alter CD22 clustering or organization in the membrane; however, these studies were performed at higher drug concentrations $(10 \mu \mathrm{M})$ and our results suggest that lower concentrations may be more appropriate in this system.(15) Treatment of cells with LatA showed no effect on the cluster size of CD22 at the concentrations tested $(0.050-0.500 \mu \mathrm{g} / \mathrm{mL})$. One explanation for this difference is the disparate mechanisms of actin disruption used by these two inhibitors.(37) Alternatively, the incubation time with LatA (30 $\mathrm{min}$ ) may have been insufficient. $(40,41)$ 


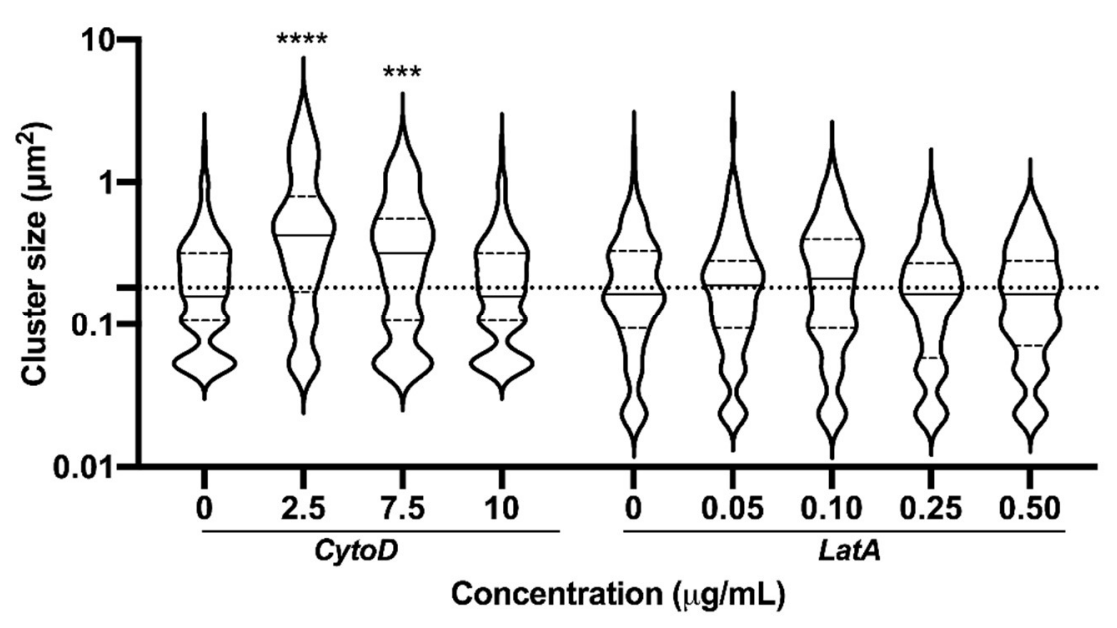

Figure 2. Cluster size of CD22 after treatment with cytoskeletal disruptors. Raji cells were treated with cytochalasin D (CytoD) or latrunculin A (LatA) at $37^{\circ} \mathrm{C}$ for $30 \mathrm{~min}$. Cells were then fixed and stained with mouse anti-CD22 and anti-mouse IgG-AF647 and imaged using confocal microscopy. Data shown are average from 30 cells among 3 biological replicates; cells were analyzed using imageJ and shown as beanplots.(14) Comparisons by student's t-test are shown relative to respective controls $(* * * *, \mathrm{p}<0.0001 ; * * *, \mathrm{p}<0.001)$.

We next investigated if cytoskeletal interactions had a significant influence on the lateral mobility (diffusion) of CD22 in the membrane. We employed single-particle tracking (SPT) using Total Internal Fluorescence Microscopy (TIRFM) to measure changes in CD22 membrane diffusion.(30) Raji cells were stained with minimal amounts of Alexa Flour 647 (AF647) conjugated primary antibody to CD22. This sparse labelling allowed visualization of CD22 trajectories on live cells, which could be converted to rates of diffusion (Figure 3).(42) This method allowed us to compare lateral diffusion of proteins in control and cytoskeleton-disrupted conditions. Treatment with CytoD at low concentration $(2.5 \mu \mathrm{g} / \mathrm{mL})$ significantly decreased CD22 
diffusion; however, at higher concentrations $(10 \mu \mathrm{g} / \mathrm{mL})$ this effect was lost. Treatment with LatA $(0.25 \mu \mathrm{g} / \mathrm{mL})$ also showed a significant decrease in lateral mobility of CD22.

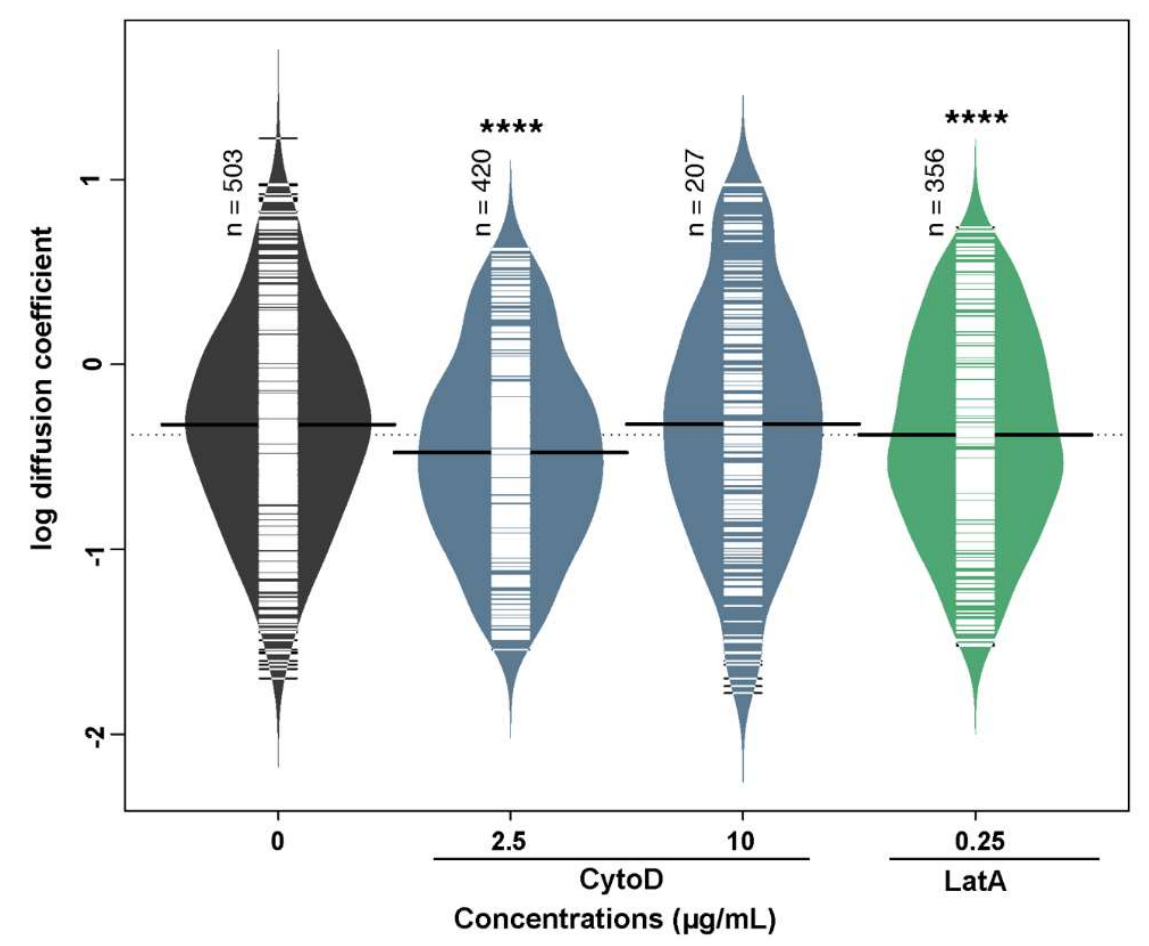

Figure 3. Lateral mobility of CD22 after treatment with cytoskeletal disruptors. Raji cells were treated at $37^{\circ} \mathrm{C}$ for $30 \mathrm{~min}$. Lateral mobility was analyzed using single-particle tracking with TIRFM videos recorded at 10 FPS for 10s.(30) Diffusion coefficients are given as log(D), where

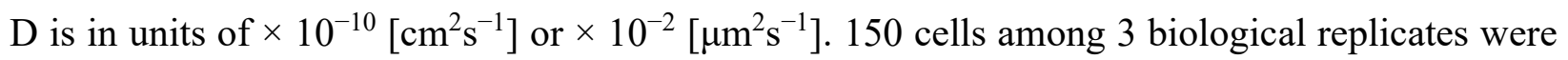
analyzed, and values were compared to control using a student's t-test $(* * * *, p<0.0001)$. Beanplots were generated using R software. Individual data points are represented by short white lines, a solid black line indicates the average for each condition, and the dotted line represents an average across all populations. 


\section{NEU1 and NEU3 activity alter CD22 cluster size}

Considering that the lectin activity of CD22 is dependent on sialylated cis ligands, we next investigated if native hNEU enzymes could alter CD22 membrane organization. CD22 is found in homotypic clusters, $(5,43)$ and also has cis interactions with other sialylated proteins, including CD45.(44-46) We developed an siRNA knockdown protocol using electroporation for NEU1 and NEU3 enzymes,(47) as lymphocytes are often difficult to transfect using lipid-based methods. The reduced expression of NEU1 and NEU3 was confirmed by western blot of the transfected cells (Figure 4A, 4B, S1). We found that B cells treated with siRNA for Neul or Neu3 had expression of the enzymes reduced by approximately half. Viability of the cells by hemocytometer after treatment showed no significant decrease for Neul siRNA, while Neu3 siRNA did show a decrease in viability (Figure S2). We proceeded to determine if NEU1 and NEU3 knockdown (KD) cells showed evidence of changes to CD22 membrane organization. Analysis of clustering in these cells found a significant increase in CD22 cluster size in NEU1 KD cells while NEU3 KD cells had a significant decrease in cluster size, suggesting these two isoenzymes play different roles in regulating CD22 organization (Figure 4B). This observation can be partly attributed to the different substrate specificities of the two enzymes - with NEU1 known to prefer glycoprotein substrates and NEU3 to prefer glycolipids.(20) Additionally, the expression levels of these two enzymes may vary in lymphoid cells, with NEU1 generally being found at higher expression in many cell types. $(48,49)$ 
A.

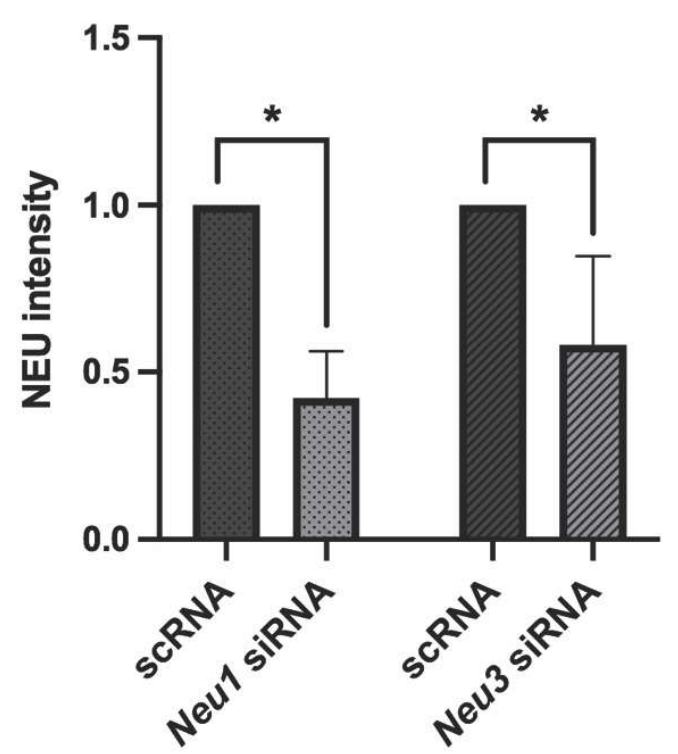

B.

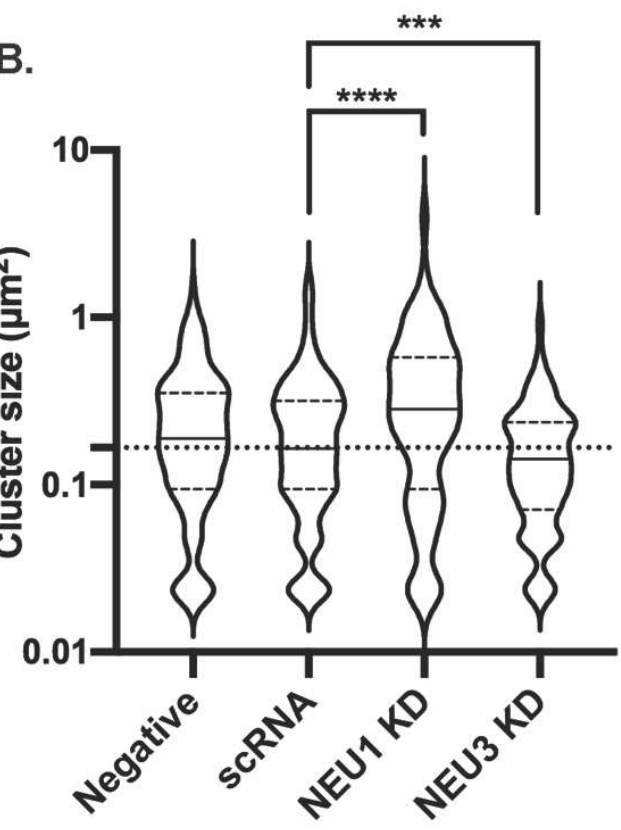

Figure 4. CD22 cluster size is altered by NEU1 and NEU3 knockdown. Raji cells were transfected with siRNA targeting Neul or Neu3 using electroporation and grown for 24 h. (A) Western blots confirmed reduced expression of NEU1 and NEU3. (B) After transfection, Raji cells were fixed and stained with mouse anti-CD22 and anti-mouse IgG-AF647 and imaged using confocal microscopy to determine the cluster size of CD22. Data shown are average from 30 cells among 3 biological replicates; cells were analyzed using imageJ and shown as beanplots.(14) Comparisons by student's t-test are shown relative to respective controls $(* * * *, p<0.001 ; * * *, p<0.005)$.

\section{Native NEU modulate B cell activation}

The $\mathrm{CD} 22$ receptor acts as a negative regulator of $\mathrm{B}$ cell activation and the organization and engagement of CD22 can alter B cell response.(50) We investigated the role of NEU1 and NEU3 in B cell activation using a calcium assay with Indo-1 dye.(51) We first asked if small molecule inhibitors of NEU enzymes had a measurable effect on B cell activation (Figure 5).(52) We used three different compounds: DANA, a pan-selective inhibitor of NEU enzymes; CG33300, a 
NEU1-selective inhibitor; and CG22600, a NEU3-selective inhibitor.(53-55) When all conditions were normalized to the control group, we observed that treating B cells with DANA increased basal activation. Additionally, cells treated with DANA and anti-IgM showed a significant increase in activation relative to control. Although these observations are consistent with native NEU activity acting as a negative regulator of $\mathrm{B}$ cell activation, they did not indicate which enzymes were involved. The selective NEU1 inhibitor, CG33300, showed similar effects to DANA - increased B cell activation relative to unstimulated and stimulated controls (Figure 5B). A selective NEU3 inhibitor, CG22600, showed similar activity - enhancing cell activation in basal and stimulated cells (Figure 5C). From these experiments, we concluded that native human NEU enzymes, including NEU1 and NEU3, act as negative regulators of B cell activation. We sought to confirm the role of NEU1 and NEU3 on B cell activation using siRNA knockdown conditions. Transfected B cells were subjected to $\mathrm{Ca}^{2+}$ assay as described above after knockdown of NEU1 or NEU3 and compared to a scRNA control (Figure 6). We found that both NEU1 and NEU3 knockdowns had increased basal $\mathrm{Ca}^{2+}$ levels in cells, consistent with our inhibitor studies. 


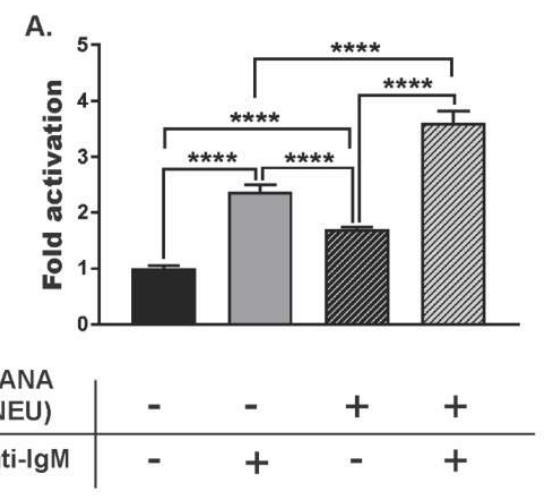

B.

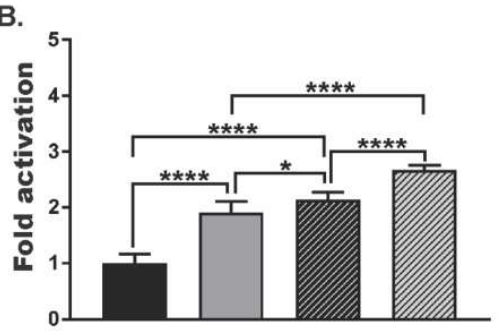

c.
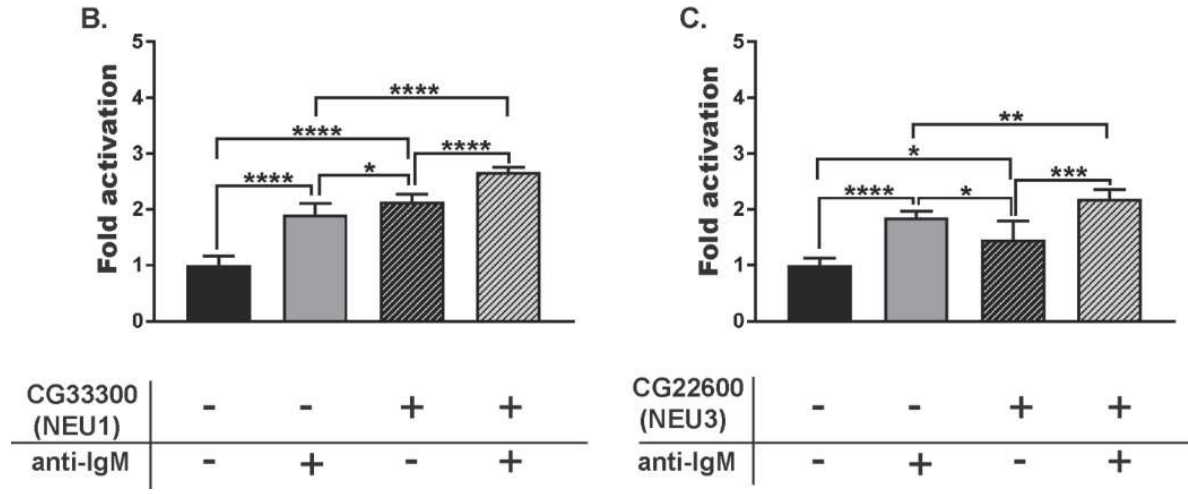

Figure 5. B cell response after treatment with NEU inhibitors. Raji cells were incubated at $37^{\circ} \mathrm{C}$ for 30 min with NEU inhibitors: (A) DANA (100 $\mu \mathrm{M})$, (B) CG33300, a NEU1 inhibitor (10 $\mu \mathrm{M})$, or (C) CG22600, a NEU3 inhibitor $(10 \mu \mathrm{M})$. Cells were either untreated (-, saline), or treated with inhibitor $(+)$; followed by activation with anti-IgM. Activation of cells was monitored by observing $\mathrm{Ca}^{2+}$ levels by Indo-1 dye. For each treatment, 6 technical replicates from each of 3 biological replicates were performed. Responses were normalized to that of saline-treated, and unstimulated control groups and compared by student's t-test $(* * * *, \mathrm{p}<0.001 ; * * *, \mathrm{p}<0.005 ; * *$, $\mathrm{p}<0.01 ; *, \mathrm{p}<0.05)$ 


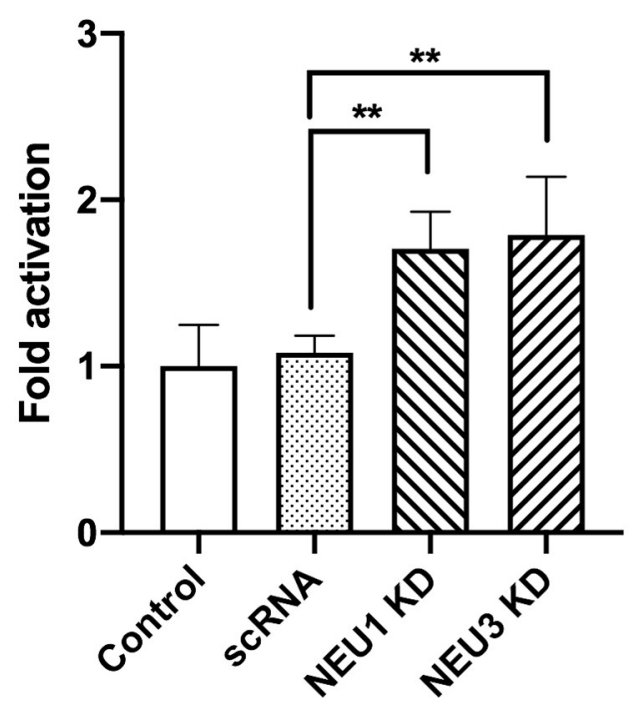

Figure 6. B cell calcium levels after NEU1 and NEU3 knockdown. Raji cells were transfected with siRNA targeting Neul, Neu3, or a scrambled control (scRNA) using electroporation. Cells were grown for $24 \mathrm{~h}$, and $\mathrm{Ca}^{2+}$ levels were monitored using Indo-1 dye. For each treatment, 2 technical replicates from each of 3 biological replicates were performed. Responses were normalized to that of saline-treated, and unstimulated control groups and compared by student's ttest $(* *, \mathrm{p}<0.01)$

One possible explanation for changes to B cell activation after siRNA transfection is differences in CD22 expression after treatment. We tested for changes in CD22 expression using western blot following siRNA treatments (Figure 7, S3). We found no significant change in CD22 expression levels in scRNA and NEU1 KD samples. However, NEU3 KD showed an unexpected decrease in CD22 expression relative to the untreated and scRNA controls. NEU3 activity has been implicated in clathrin-dependent endocytosis and could influence transport and expression of CD22.(56-59) 


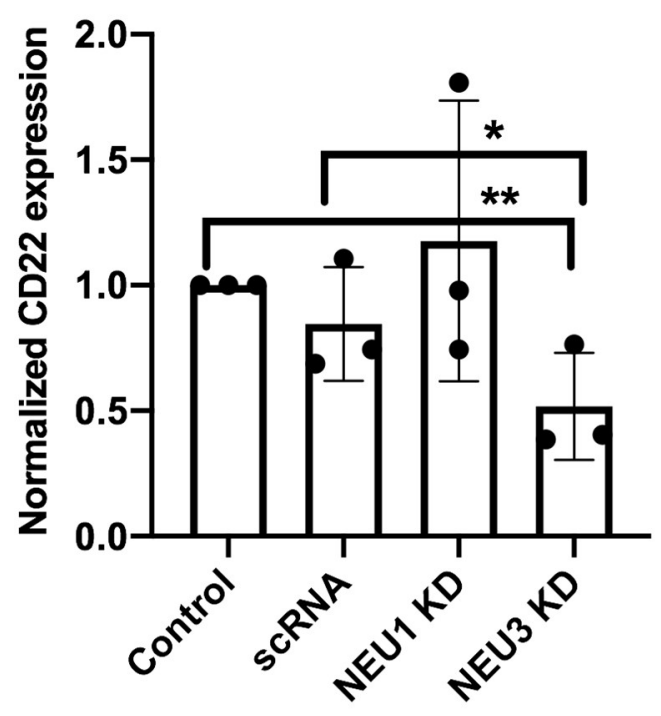

Figure 7. CD22 expression after NEU1 and NEU3 knockdown. Raji cells were transfected with siRNA targeting Neu1, Neu3, or a scrambled control (scRNA) using electroporation. Cells were allowed to grow for $24 \mathrm{~h}$, and then harvested. A western blot was performed using anti-CD22 to compare expression levels and analyzed by densitometry using ImageJ $(* *, p<0.01 ; *, p<0.05)$.

\section{Exogenous NEU affect CD22 organization and B cell activation}

A common strategy for probing the role of membrane sialosides in signaling is to treat cells with exogenous NEU enzymes. Typical examples include the sialidase from Athrobacter ureafaciens (siaAU) and NanI from Clostridium perfringens. These enzymes have different specificities, with siaAU having broad activity to cleave $\alpha 2,3$ and $\alpha 2,6$-linkages; $(60,61)$ while the latter prefers $\alpha 2,3$-linked sialosides.(62) It is worth noting that these enzymes have different substrate specificity from human NEU isoenzymes, and may not be good biochemical proxies for the native enzymes.(63) We found that treatment of B cells with NanI and siaAU generally increased clustering of CD22 (Figure S4A, S4C) but not BCR (Figure S5). We noted that the effect on CD22 cluster size was dependent on the activity of enzyme used - with high specific activity of siaAU $(10 \mathrm{mU} / \mathrm{mL})$ reversing significant increases seen at lower activity $(5 \mathrm{mU} / \mathrm{mL})$. 
Analysis of B cells treated with these enzymes by SPT found that CD22 lateral mobility was significantly reduced for both NanI and siaAU treatment (Figure 8). This result is similar to observations with CytoD treatment, where increased clustering of CD22 was coincident with decreased lateral mobility.

We next investigated if exogenous human NEU3 enzyme had similar effects to the bacterial NEU enzymes on clustering and diffusion of CD22. When B cells were treated with NEU3 (10 $\mathrm{mU} / \mathrm{mL}$ ) clustering of CD22 significantly increased, consistent with the effect of the bacterial enzymes (Figure S4B). Measurements of the lateral mobility of CD22 after NEU3 treatment showed an increase in diffusion (Figure 8). We performed an analysis of B cell glycosphingolipids after exogenous NEU treatment using LC-MS (Figure S6),(30) in which we observed no significant changes for any of the enzyme treatments. This may suggest that changes to glycosphingolipid composition are not the major factor in changes to CD22 organization, or that these changes in composition are below the detection limit of our assay. An alternative explanation for changes to CD22 organization is that exogenous NEU enzymes modify CD22 glycosylation, thus altering homotypic clustering. Using purified CD22, we confirmed that NanI and siaAU reduced SNA staining and increased PNA staining for CD22, consistent with desialylation of the receptor in vitro (Figure S7, S8). 


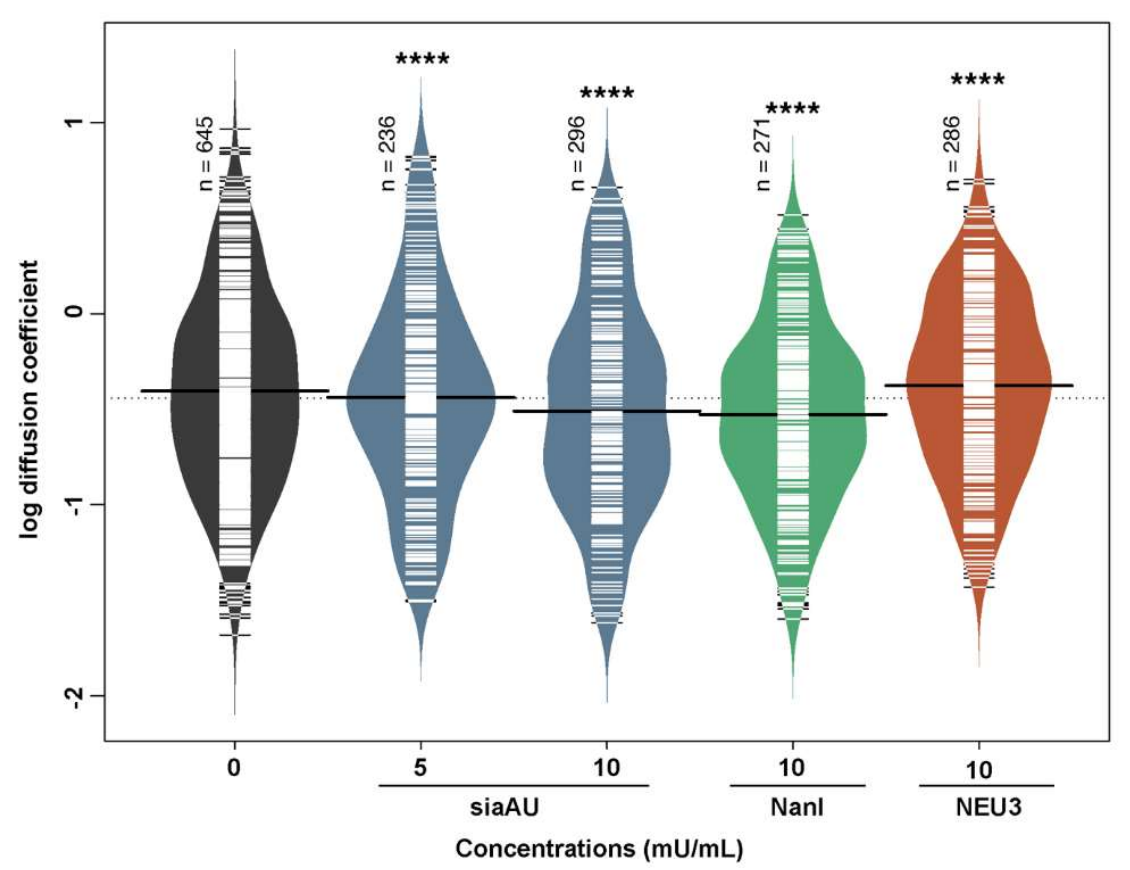

Figure 8. Lateral mobility of CD22 after treatment with NEU enzymes. Raji cells were treated at $37^{\circ} \mathrm{C}$ for $30 \mathrm{~min}$. Lateral mobility was analyzed using single-particle tracking with TIRFM videos recorded at 10 FPS for 10s.(30) Diffusion coefficients are given as $\log (\mathrm{D})$, where D is in units of $\times 10^{-10}\left[\mathrm{~cm}^{2} \mathrm{~s}^{-1}\right]$ or $\times 10^{-2}\left[\mu \mathrm{m}^{2} \mathrm{~s}^{-1}\right]$. Data shown are from 150 cells among 3 biological replicates, data were analyzed, and compared to control using a student's t-test $(* * * *, p<0.001)$.

During our studies, we encountered an issue that may complicate experiments which use exogenous bacterially-produced NEU. Exogenous enzymes from bacterial sources may contain lipopolysaccharide (LPS), and this contaminant may affect lymphocyte activation(64-66) or CD22 expression.(67) We found that samples of siaAU and NanI from commercial sources contained more than $1 \mathrm{EU} / \mathrm{mL}(\mathrm{EU}=$ endotoxin units, $1 \mathrm{EU}=0.1$ to $0.2 \mathrm{ng})$, with final LPS concentrations in our experiments of 0.0001 to $0.01 \mathrm{ng} / \mathrm{mL}$. We tested whether these amounts of LPS alone could affect CD22 clustering (Figure S9). We observed a significant increase in CD22 clustering at 0.01 
$\mathrm{ng} / \mathrm{mL}$ of LPS in our assay, while higher concentrations attenuated this effect $(0.1 \mathrm{ng} / \mathrm{mL})$. Additionally, determinations of $\mathrm{B}$ cell activation using $\mathrm{Ca}^{2+}$ level assays after treatment with exogenous siaAU or NanI were ambiguous in our hands (Figure S10). For example, siaAU at lower concentrations had similar effects to treatment with DANA (Figure S10A versus Figure 5A) despite the fact that these treatments should have opposite effects on sialic acid content on cells. Higher concentrations of siaAU attenuated this effect (Figure S10B), while NanI treatment showed no significant differences from control (Figure S10C).

\section{DISCUSSION}

The data described here provide critical insight into the effects of native and exogenous NEU enzymes on CD22 organization on B cells. The organization of CD22 on the membrane is dependant on the lectin activity of the receptor and the availability of sialoglycoproteins in the milieu of the plasma membrane. We set out to understand if native NEU enzymes, which help regulate levels of sialyation of glycolipids and glycoproteins, could influence CD22 organization. Using confocal microscopy and single-particle tracking we demonstrated that CD22 has interactions with the cytoskeleton, though we did not resolve the nature of this interaction. We found that native NEU1 and NEU3 activity influenced both the size of CD22 clusters and their mobility within the membrane. Based on our results, we conclude that increased NEU1 activity led to smaller CD22 clusters. In contrast, increased NEU3 activity (both native or exogenous) generated larger CD22 clusters which had increased diffusion. Moreover, exogenous bacterial NEU activity generated larger CD22 clusters with decreased diffusion. These stark differences

were likely the result of different substrate specificities for each enzyme. Importantly, we confirmed that LPS contamination in exogenous enzyme preparations influenced CD22 
organization and could complicate attempts to use these reagents to understand the role of CD22 interactions with cis sialoside ligands. Furthermore, we confirmed that native NEU activity influenced $\mathrm{B}$ cell response to $\mathrm{BCR}$ clustering using a $\mathrm{Ca}^{2+}$ assay. Knockdown or chemical inhibition of both NEU1 and NEU3 enzymes resulted in increased basal activation of B cells, consistent with these enzymes acting as negative regulators of B cell stimulation. Our studies clearly support the involvement of the cytoskeleton and NEU enzymes in regulating CD22 organization and B cell activity.

Lateral mobility of immune cell receptors is complex and can be influenced by a number of factors(68) such as the lateral size of the protein,(69) cytoskeletal barriers,(70-73) the presence of membrane microdomains,(74) and crowding effects.(75) Studies have proposed CD22,(15) CD45,(76) and BCR(77,78) are associated with membrane microdomains in lymphocytes.(19,79) CD22 is not thought to have direct contacts to the cytoskeleton; though cis ligands could provide indirect contacts. In studies of CD22-cytoskeleton interactions, we found that SPT was more sensitive to changes in cluster size than confocal microscopy. Furthermore, we examined CD22cytoskeleton interactions using a range of CytoD concentrations $(2.5-10 \mu \mathrm{g} / \mathrm{mL})$, while previous studies tested only a single concentration and found no effect.(15) The interaction of CD22 with the cytoskeleton was complex, and our data indicated that with low concentrations of CytoD (2.5 $\mu \mathrm{g} / \mathrm{mL}$ ) CD22 was found in larger clusters with reduced lateral mobility. These data cannot resolve whether CD22-cytoskeleton contacts are direct or indirect, but it is well known that this receptor is found in homotypic clusters,(5) and has cis-binding interactions with sialoglycoproteins, such as CD45.(6,15,44,80) Notably, CD45 is associated with the cytoskeleton through a spectrinankyrin complex which regulates its lateral mobility, providing a likely explanation for these findings.(81-83) 
As a Siglec that engages cis ligands, CD22 organization could be expected to be influenced by mechanisms that regulate membrane sialoglycoproteins. Previous work has found changes to CD22 organization from altered sialyltransferase expression, CD45 expression, lectin activity of CD22, and altered glycosylation sites on CD22.(15,50,84,85) This work is the first to explore the role of native NEU enzymes in CD22 organization. We found that NEU1 and NEU3 had a role in CD22 clustering, and our data suggest that isoenzymes could play disparate roles in B cell regulation. There is growing recognition that native NEU enzymes may play important roles in inflammation and immune cells. $(22,30,86,87)$ We propose that further investigation of the role of these enzymes in B cell regulation is needed.

A common strategy to perturb CD22-ligand interactions is to treat cells with exogenous NEU. Many examples have tested the effect of exogenous bacterial NEU enzymes on CD22 organization and activity.(15,50) While these reagents may reveal aspects of CD22-ligand interactions, they may not report on the role of native NEU isoenzymes. The substrate preferences of bacterial enzymes and native NEU are different. For example, enzymes like NanI prefer glycoprotein substrates, while NEU3 prefers glycolipids.(88,89) Glycosphingolipids are a major component of membrane microdomains, and these membrane components may be modulated by NEU3 activity.(90) Bacterially-produced enzymes may also be contaminated with LPS, which we observed could alter CD22 clustering. Thus, we suggest that results based on the use of bacteriallyproduced enzyme be interpreted with caution; and we favor the use of small molecule inhibitors or knockdown of NEU expression to avoid this complication. 


\section{Acknowledgements}

The authors would like to thank Dr. Matthew Macauley for providing murine hybridoma cells expressing anti-CD22 antibodies. This work was supported by grants from the Natural Sciences and Engineering Research Council of Canada (NSERC RGPIN-2020-04371) and the Canadian Glycomics Network (GlycoNet).

\section{Author contributions}

Conceived and designed experiments: CWC, HTT, CL

Performed experiments and analyzed data: HTT, RC, CL

Wrote the manuscript: CWC, HTT

\section{Conflict of interest}

CWC is a co-inventor of a patent describing NEU inhibitors used in this study.

\section{Supplementary material}

The Supplementary Material for this article can be found online at xxx.

Figure S1. Western blots of NEU knockdowns. Raji cells were transfected with siRNA targeting Neu1 and Neu3 using electroporation and grown for 24 hours. Western blots show the reduction of expression of hNEU1 (A) and hNEU3 (B). Shown are representative blots of three replicates for each NEU.

Figure S2. Raji cell viability after siRNA transfection. Raji cells were transfected with siRNA targeting Neu1, Neu3, or a scrambled control (scRNA) using electroporation and grown for 24 hours. The viability of cells from each condition was determined using trypan blue dye exclusion on a hemocytometer. 
Figure S3. Western blot of CD22 expression after NEU1 and NEU3 knockdown. Raji cells were transfected with siRNA targeting Neu1, Neu3, or a scrambled control (scRNA) using electroporation. Cells were allowed to grow for $24 \mathrm{~h}$, and then harvested. A western blot was performed using anti-CD22 to compare expression levels and analyzed by densitometry using imageJ. Shown is representative blot of three replicates.

Figure S4. Cluster size of CD22 after treatment with NEU enzymes. Raji cells were treated with bacterial NEU (A) or human NEU enzymes (B) at the indicated concentrations at 37 ${ }^{\circ} \mathrm{C}$ for $30 \mathrm{~min}$. Cells were then fixed and stained with mouse anti-IgM and anti-mouse IgG-AF647 and imaged using confocal microscopy (C). Ten cells from each condition were analyzed using ImageJ and are shown as beanplots. Bottom right: confocal images of Raji cells stained with antiCD22 antibody. Comparisons by student's t-test are shown relative to respective controls (***, p $<0.005 ; *, \mathrm{p}<0.05)$.

Figure S5. Cluster size of BCR after treatment with NEU enzymes. Raji cells were treated with NanI, siaAU, or NEU3 enzyme at $37^{\circ} \mathrm{C}$ for $30 \mathrm{~min}$. Cells were then fixed and stained with mouse anti-IgM and anti-mouse IgG-AF647 and imaged using confocal microscopy. Ten cells from each condition were analyzed using ImageJ and are shown as beanplots.

Figure S6. Glycolipid composition of Raji cells after NEU treatment. Raji cells were treated with saline, siaAU $(5 \mathrm{mU} / \mathrm{mL})$, siaAU $(10 \mathrm{mU} / \mathrm{mL})$, NanI $(10 \mathrm{mU} / \mathrm{mL})$, or NEU3 $(10$ $\mathrm{mU} / \mathrm{mL}$ ) for $30 \mathrm{~min}$ at $37^{\circ} \mathrm{C}$. Cells were then subjected to glycolipid analysis using LC-MS. Data shown are the average of four replicates.

Figure S7. Lectin blots of purified CD22 protein treated with NEU enzymes. CD22 was purified from Raji cells using an immunoaffinity column. The protein was treated with (-) saline 
or (+) NEU enzymes (A) siaAU $(5 \mathrm{mU} / \mathrm{mL})$ or (B) NanI $(10 \mathrm{mU} / \mathrm{mL})$ for 30 minutes at $37{ }^{\circ} \mathrm{C}$. Samples were then analyzed by lectin blotting with PNA, SNA, or MAL probes.

Figure S8. Quantification of NEU-treated CD22 protein. CD22 samples treated with (-) saline or (+) NEU enzymes (A) siaAU (5 mU/mL) or (B) NanI $(10 \mathrm{mU} / \mathrm{mL})$. Purified proteins were incubated with corresponding neuraminidase for $30 \mathrm{~min}$ at $37{ }^{\circ} \mathrm{C}$. Samples were then analyzed by lectin blotting with PNA, SNA, or MAL probes, and images were quantified using densitometry.

Figure S9. Cluster size of CD22 after treatment with LPS. Cluster size of CD22 using confocal microscopy. Raji cells were treated with LPS at $37^{\circ} \mathrm{C}$ for $30 \mathrm{~min}$. Cells were then fixed and stained with mouse anti-IgM and anti-mouse IgG-AF647 and imaged using confocal microscopy. Ten cells from each condition were analyzed using ImageJ and are shown as beanplots.22 Comparisons by student's t-test are shown relative to respective controls $(*, p<0.5)$.

Figure S10. B cell response after treatment with NEU enzymes. Raji cells were incubated at $37{ }^{\circ} \mathrm{C}$ for 30 min with NEU enzymes: (A) sialidase from Athrobacter ureafaciens (siaAU) at 5 $\mathrm{mU} / \mathrm{mL},(B)$ siaAU at $10 \mathrm{mU} / \mathrm{mL}$, or (C) NanI at $10 \mathrm{mU} / \mathrm{mL}$. Cells were either untreated (-, saline), or treated with enzyme $(+)$; followed by activation with anti-IgM. Activation of cells was monitored by observing Ca2+ levels monitored by Indo-1 dye. Responses were normalized to that of saline-treated, and unstimulated control groups and compared by student's t-test $(* * * *, p<$ $0.001 ; * * *, \mathrm{p}<0.005 ; * *, \mathrm{p}<0.01 ; *, \mathrm{p}<0.05)$ 


\section{REFERENCES}

1. Nitschke L, Carsetti R, Ocker B, Köhler G, Lamers MC. CD22 is a negative regulator of Bcell receptor signalling. Curr Biol (1997) 7:133-143. doi:10.1016/S0960-9822(06)00057-1

2. Ereño-Orbea J, Sicard T, Cui H, Mazhab-Jafari MT, Benlekbir S, Guarné A, Rubinstein JL, Julien J-P. Molecular basis of human CD22 function and therapeutic targeting. Nat Commun (2017) 8:1-11. doi:10.1038/s41467-017-00836-6

3. Doody G, Justement L, Delibrias C, Matthews R, Lin J, Thomas M, Fearon D. A role in B cell activation for CD22 and the protein tyrosine phosphatase SHP. Science (1995) 269:242244. doi:10.1126/science. 7618087

4. Razi N, Varki A. Masking and unmasking of the sialic acid-binding lectin activity of CD22 (Siglec-2) on B lymphocytes. Proc Natl Acad Sci (1998) 95:7469-7474. doi:10.1073/pnas.95.13.7469

5. Han S, Collins BE, Bengtson P, Paulson JC. Homomultimeric complexes of CD22 in B cells revealed by protein-glycan cross-linking. Nat Chem Biol (2005) 1:93-97. doi:10.1038/nchembio713

6. Sgroi D, Koretzky GA, Stamenkovic I. Regulation of CD45 engagement by the B-cell receptor CD22. Proc Natl Acad Sci (1995) 92:4026-4030. doi:10.1073/pnas.92.9.4026

7. Law CL, Aruffo A, Chandran KA, Doty RT, Clark EA. Ig domains 1 and 2 of murine CD22 constitute the ligand-binding domain and bind multiple sialylated ligands expressed on $\mathrm{B}$ and T cells. 1995 155:3368-3376.

8. Nitschke L. CD22 and Siglec-G: B-cell inhibitory receptors with distinct functions. Immunol $\operatorname{Rev}(2009)$ 230:128-143. doi:10.1111/j.1600-065X.2009.00801.x

9. Collins BE, Blixt O, Han S, Nathan JK, Bovin N, Paulson JC. High-Affinity Ligand Probes of CD22 Overcome the Threshold Set by cis Ligands to Allow for Binding, Endocytosis, and Killing of B Cells. J Immunol (2006) 177:2994-3003. doi:10.4049/jimmunol.177.5.2994

10. Courtney AH, Puffer EB, Pontrello JK, Yang Z-Q, Kiessling LL. Sialylated multivalent antigens engage CD22 in trans and inhibit B cell activation. Proc Natl Acad Sci (2009) 106:2500-2505. doi:10.1073/pnas.0807207106

11. Macauley MS, Pfrengle F, Rademacher C, Nycholat CM, Gale AJ. Antigenic liposomes displaying CD22 ligands induce antigen-specific B cell apoptosis. J Clin Invest (2013) 123:3074-3083. doi:https://doi.org/10.1172/JCI69187

12. Chen WC, Completo GC, Sigal DS, Crocker PR, Saven A, Paulson JC. In vivo targeting of B-cell lymphoma with glycan ligands of CD22. Blood (2010) 115:4778-4786. doi:10.1182/blood-2009-12- 257386 
13. Duong BH, Tian H, Ota T, Completo G, Han S, Vela JL, Ota M, Kubitz M, Bovin N, Paulson $\mathrm{JC}$, et al. Decoration of T-independent antigen with ligands for CD22 and Siglec-G can suppress immunity and induce B cell tolerance in vivo. J Exp Med (2010) 207:173-187. doi:10.1084/jem.20091873

14. Daskhan GC, Tran H-TT, Meloncelli PJ, Lowary TL, West LJ, Cairo CW. Construction of Multivalent Homo- and Heterofunctional ABO Blood Group Glycoconjugates Using a Trifunctional Linker Strategy. Bioconjug Chem (2018) 29:343-362. doi:10.1021/acs.bioconjchem.7b00679

15. Gasparrini F, Feest C, Bruckbauer A, Mattila PK, Müller J, Nitschke L, Bray D, Batista FD. Nanoscale organization and dynamics of the siglec CD 22 cooperate with the cytoskeleton in restraining BCR signalling. EMBOJ (2016) 35:258-280. doi:10.15252/embj.201593027

16. He X, Woodford-Thomas TA, Johnson KG, Shah DD, Thomas ML. Targeting of CD45 protein tyrosine phosphatase activity to lipid microdomains on the T cell surface inhibits TCR signaling. Eur $J$ Immunol (2002) 32:2578-2587. doi:10.1002/15214141(200209)32:9<2578::AID-IMMU2578>3.0.CO;2-3

17. Edmonds SD, Ostergaard HL. Dynamic Association of CD45 with Detergent-Insoluble Microdomains in $T$ Lymphocytes. $J$ Immunol (2002) 169:5036-5042. doi:https://doi.org/10.4049/jimmunol.169.9.5036

18. Guo B, Kato RM, Garcia-Lloret M, Wahl MI, Rawlings DJ. Engagement of the Human PreB Cell Receptor Generates a Lipid Raft-Dependent Calcium Signaling Complex. Immunity (2000) 13:243-253. doi:10.1016/S1074-7613(00)00024-8

19. Gupta N, DeFranco AL. Visualizing Lipid Raft Dynamics and Early Signaling Events during Antigen Receptor-mediated B-Lymphocyte Activation $\square$ V. Mol Biol Cell (2003) 14:432-444. doi:www.molbiolcell.org/cgi/doi/10.1091/mbc.02-05-0078.

20. Miyagi T, Yamaguchi K. Mammalian sialidases: physiological and pathological roles in cellular functions. Glycobiology (2012) 22:880-896.

21. Glanz VYu, Myasoedova VA, Grechko AV, Orekhov AN. Sialidase activity in human pathologies. Eur J Pharmacol (2019) 842:345-350. doi:10.1016/j.ejphar.2018.11.014

22. Demina Ekaterina P., Smutova Victoria, Pan Xuefang, Fougerat Anne, Guo Tianlin, Zou Chunxia, Chakraberty Radhika, Snarr Brendan D., Shiao Tze C., Roy Rene, et al. Neuraminidases 1 and 3 Trigger Atherosclerosis by Desialylating Low-Density Lipoproteins and Increasing Their Uptake by Macrophages. J Am Heart Assoc (2021) 10:e018756. doi:10.1161/JAHA.120.018756

23. Kato T, Wang Y, Yamaguchi K, Milner CM, Shineha R, Satomi S, Miyagi T. Overexpression of lysosomal-type sialidase leads to suppression of metastasis associated with reversion of malignant phenotype in murine B16 melanoma cells. Int J Cancer (2001) 92:797-804. doi:10.1002/ijc.1268 
24. Sawada M, Moriya S, Saito S, Shineha R, Satomi S, Yamori T, Tsuruo T, Kannagi R, Miyagi T. Reduced sialidase expression in highly metastatic variants of mouse colon adenocarcinoma 26 and retardation of their metastatic ability by sialidase overexpression. Int J Cancer (2002) 97:180-185. doi:10.1002/ijc. 1598

25. Silvestri I, Testa F, Zappasodi R, Cairo CW, Zhang Y, Lupo B, Galli R, Di Nicola M, Venerando B, Tringali C. Sialidase NEU4 is involved in glioblastoma stem cell survival. Cell Death Dis (2014) 5:e1381. doi:10.1038/cddis.2014.349

26. Seyrantepe V, Demir SA, Timur ZK, Von Gerichten J, Marsching C, Erdemli E, Oztas E, Takahashi K, Yamaguchi K, Ates N, et al. Murine Sialidase Neu3 facilitates GM2 degradation and bypass in mouse model of Tay-Sachs disease. Exp Neurol (2018) 299:2641. doi:10.1016/j.expneurol.2017.09.012

27. Seyrantepe V, Landry K, Trudel S, Hassan JA, Morales CR, Pshezhetsky AV. Neu4, a Novel Human Lysosomal Lumen Sialidase, Confers Normal Phenotype to Sialidosis and Galactosialidosis Cells. $J$ Biol Chem (2004) 279:37021-37029. doi:10.1074/jbc.M404531200

28. Hasegawa T, Sugeno N, Takeda A, Matsuzaki-Kobayashi M, Kikuchi A, Furukawa K, Miyagi T, Itoyama Y. Role of Neu4L sialidase and its substrate ganglioside GD3 in neuronal apoptosis induced by catechol metabolites. FEBS Lett (2007) 581:406-412. doi:10.1016/j.febslet.2006.12.046

29. Igdoura S. Sialidase-mediated depletion of GM2 ganglioside in Tay-Sachs neuroglia cells. Hum Mol Genet (1999) 8:1111-1116. doi:10.1093/hmg/8.6.1111

30. Howlader MA, Li C, Zou C, Chakraberty R, Ebesoh N, Cairo CW. Neuraminidase-3 Is a Negative Regulator of LFA-1 Adhesion. Front Chem (2019) 7: doi:10.3389/fchem.2019.00791

31. Tolar P, Hanna J, Krueger PD, Pierce SK. The Constant Region of the Membrane Immunoglobulin Mediates B Cell-Receptor Clustering and Signaling in Response to Membrane Antigens. Immunity (2009) 30:44-55. doi:10.1016/j.immuni.2008.11.007

32. Harwood NE, Batista FD. The Cytoskeleton Coordinates the Early Events of B-cell Activation. Cold Spring Harb Perspect Biol (2011) 3:a002360-a002360. doi:10.1101/cshperspect.a002360

33. Treanor B, Depoil D, Gonzalez-Granja A, Barral P, Weber M, Dushek O, Bruckbauer A, Batista FD. The Membrane Skeleton Controls Diffusion Dynamics and Signaling through the B Cell Receptor. Immunity (2010) 32:187-199. doi:10.1016/j.immuni.2009.12.005

34. Schliwa M. Action of cytochalasin D on cytoskeletal networks. J Cell Biol (1982) 92:79-91. doi:10.1083/jcb.92.1.79

35. Goddette DW, Frieden C. The actin polymerization. The mechanism of action of Cytochalasin D. J Biol Chem (1986) 261:15974-15980. 
36. Morton WM, Ayscough KR, McLaughlin PJ. Latrunculin alters the actin-monomer subunit interface to prevent polymerization. Nat Cell Biol (2000) 2:376-378. doi:10.1038/35014075

37. Coué M, Brenner SL, Spector I, Korn ED. Inhibition of actin polymerization by latrunculin A. FEBS Lett (1987) 213:316-318. doi:10.1016/0014-5793(87)81513-2

38. Wakatsuki T. Actin polymerization and cell mechanics. J Cell Sci (2001) 114:1025-1036.

39. Stevenson BR, Begg DA. Concentration-dependent effects of cytochalasin D on tight junctions and actin filaments in MDCK epithelial cells. J Cell Sci (1994) 107:367-375.

40. Cai S, Liu X, Glasser A, Volberg T, Filla M, Geiger B, Polansky JR, Kaufman PL. Effect of latrunculin-A on morphology and actin-associated adhe- sions of cultured human trabecular meshwork cells. Mol Vis (2000) 6:132-143.

41. Foissner I, Wasteneys GO. Wide-Ranging Effects of Eight Cytochalasins and Latrunculin A and B on Intracellular Motility and Actin Filament Reorganization in Characean Internodal Cells. Plant Cell Physiol (2007) 48:587-597. doi:10.1093/pcp/pcm030

42. Jaqaman K, Loerke D, Mettlen M, Kuwata H, Grinstein S, Schmid SL, Danuser G. Robust single-particle tracking in live-cell time-lapse sequences. Nat Methods (2008) 5:695-702. doi: $10.1038 /$ nmeth. 1237

43. Ramya TNC, Weerapana E, Liao L, Zeng Y, Tateno H, Liao L, Yates JR, Cravatt BF, Paulson JC. In situ trans ligands of CD22 identified by glycan-protein photocross-linking-enabled proteomics. Mol Cell Proteomics MCP (2010) 9:1339-1351. doi:10.1074/mcp.m900461$\operatorname{mcp} 200$

44. Zhang M. Cell surface sialic acids do not affect primary CD22 interactions with CD45 and surface IgM nor the rate of constitutive CD22 endocytosis. Glycobiology (2004) 14:939-949. doi:10.1093/glycob/cwh126

45. Coughlin S, Noviski M, Mueller JL, Chuwonpad A, Raschke WC, Weiss A, Zikherman J. An extracatalytic function of CD45 in B cells is mediated by CD22. Proc Natl Acad Sci (2015) 112:E6515. doi:10.1073/pnas.1519925112

46. Alborzian Deh Sheikh A, Akatsu C, Imamura A, Abdu-Allah HHM, Takematsu H, Ando H, Ishida H, Tsubata T. Proximity labeling of cis-ligands of CD22/Siglec-2 reveals stepwise a2,6 sialic acid-dependent and -independent interactions. Biochem Biophys Res Commun (2018) 495:854-859. doi:10.1016/j.bbrc.2017.11.086

47. Heiser WC. "Optimizing Electroporation Conditions for the Transformation of Mammalian Cells," in Transcription Factor Protocols, ed. M. J. Tymms (Totowa, NJ: Humana Press), 117-134. doi:10.1385/1-59259-686-X:117

48. Kaminuma O, Katoh S, Miyagi T, Watanabe N, Kitamura N, Nishimura T, Saeki M, Mori A, Hiroi T. Contribution of neuraminidase 3 to the differentiation of induced regulatory T cells. Genes Cells (2017) doi:10.1111/gtc.12553 
49. Nan X, Carubelli I, Stamatos NM. Sialidase expression in activated human T lymphocytes influences production of IFN- $\gamma$. J Leukoc Biol (2007) 81:284-296. doi:10.1189/jlb.1105692

50. Meyer SJ, Linder AT, Brandl C, Nitschke L. B Cell Siglecs-News on Signaling and Its Interplay With Ligand Binding. Front Immunol (2018) 9:2820. doi:10.3389/fimmu.2018.02820

51. Grynkiewicz G, Poenie M, TsienB RY. A New Generation of Ca2+ Indicatorswith Greatly Improved Fluorescence Properties. $J$ Biol Chem (1985) 260:3440-3450. doi:https://doi.org/10.1016/S0021-9258(19)83641-4

52. Cairo CW. Inhibitors of the human neuraminidase enzymes. MedChemComm (2014) 5:10671074. doi:10.1039/C4MD00089G

53. Richards MR, Guo T, Hunter CD, Cairo CW. Molecular dynamics simulations of viral neuraminidase inhibitors with the human neuraminidase enzymes: Insights into isoenzyme selectivity. Bioorg Med Chem (2018) 26:5349-5358. doi:10.1016/j.bmc.2018.05.035

54. Guo T, Dätwyler P, Demina E, Richards MR, Ge P, Zou C, Zheng R, Fougerat A, Pshezhetsky AV, Ernst B, et al. Selective Inhibitors of Human Neuraminidase 3. J Med Chem (2018) 61:1990-2008. doi:10.1021/acs.jmedchem.7b01574

55. Guo T, Héon-Roberts R, Zou C, Zheng R, Pshezhetsky AV, Cairo CW. Selective Inhibitors of Human Neuraminidase 1 (NEU1). $J$ Med Chem (2018) 61:11261-11279. doi:10.1021/acs.jmedchem.8b01411

56. Rodriguez-Walker M, Daniotti JL. Human Sialidase Neu3 is S-Acylated and Behaves Like an Integral Membrane Protein. Sci Rep (2017) 7:4167. doi:10.1038/s41598-017-04488-w

57. Wada T, Hata K, Yamaguchi K, Shiozaki K, Koseki K, Moriya S, Miyagi T. A crucial role of plasma membrane-associated sialidase in the survival of human cancer cells. Oncogene (2007) 26:2483-2490. doi:10.1038/sj.onc.1210341

58. Papini N, Anastasia L, Tringali C, Croci G, Bresciani R, Yamaguchi K, Miyagi T, Preti A, Prinetti A, Prioni S, et al. The Plasma Membrane-associated Sialidase MmNEU3 Modifies the Ganglioside Pattern of Adjacent Cells Supporting Its Involvement in Cell-to-Cell Interactions. J Biol Chem (2004) 279:16989-16995. doi:10.1074/jbc.M400881200

59. Kakugawa Y, Wada T, Yamaguchi K, Yamanami H, Ouchi K, Sato I, Miyagi T. Upregulation of plasma membrane-associated ganglioside sialidase (Neu3) in human colon cancer and its involvement in apoptosis suppression. Proc Natl Acad Sci (2002) 99:1071810723. doi:10.1073/pnas. 152597199

60. Uchida Y, Tsukada Y, Sugimori T. Enzymatic Properties of Neuraminidases from Arthrobacter ureafaciens. $J$ Biochem (Tokyo) (1979) 86:1573-1585. doi:10.1093/oxfordjournals.jbchem.a132675 
61. Ohta Y, Tsukada Y, Sugimori T. Purification and Properties of Neuraminidase Isozymes in Arthrobacter ureafaciens Mutant. $J$ Biochem (Tokyo) (1989) 106:1086-1089. doi:10.1093/oxfordjournals.jbchem.a122969

62. Wang Y. Sialidases From Clostridium perfringens and Their Inhibitors. Front Cell Infect Microbiol (2020) 9:11. doi:0.3389/fcimb.2019.00462

63. Miyagi T, Yamaguchi K. Mammlian sialidases: physiological and pathological roles in cellular functions. Glycobiology (2012) 22:880-896. doi:10.1093/glycob/cws057

64. Sato S, Miller AS, Inaoki M, Bock CB, Jansen PJ, Tang MLK, Tedder TF. CD22 Is Both a Positive and Negative Regulator of B Lymphocyte Antigen Receptor Signal Transduction: Altered Signaling in CD22-Deficient Mice. Immunity (1996) 5:551-562. doi:10.1016/S10747613(00)80270-8

65. Rahman H, Qasim M, Schultze FC, Oellerich M, R Asif A. Fetal calf serum heat inactivation and lipopolysaccharide contamination influence the human T lymphoblast proteome and phosphoproteome. Proteome Sci (2011) 9:71. doi:10.1186/1477-5956-9-71

66. Koenig S, Hoffmann MK. Bacterial lipopolysaccharide activates suppressor B lymphocytes. Proc Natl Acad Sci (1979) 76:4608-4612. doi:10.1073/pnas.76.9.4608

67. Lajaunias F, Nitschke L, Moll T, Martinez-Soria E, Semac I, Chicheportiche Y, Parkhouse RME, Izui S. Differentially Regulated Expression and Function of CD22 in Activated B-1 and B-2 Lymphocytes. J Immunol (2002) 168:6078. doi:10.4049/jimmunol.168.12.6078

68. Cairo CW, Golan DE. T cell adhesion mechanisms revealed by receptor lateral mobility. Biopolymers (2008) 89:409-419.

69. Ramadurai S, Holt A, Krasnikov V, van den Bogaart G, Killian JA, Poolman B. Lateral Diffusion of Membrane Proteins. $J$ Am Chem Soc (2009) 131:12650-12656. doi:10.1021/ja902853g

70. Auth T, Gov NS. Diffusion in a Fluid Membrane with a Flexible Cortical Cytoskeleton. Biophys J (2009) 96:818-830. doi:10.1016/j.bpj.2008.10.038

71. Saha S, Lee I-H, Polley A, Groves JT, Rao M, Mayor S. Diffusion of GPI-anchored proteins is influenced by the activity of dynamic cortical actin. Mol Biol Cell (2015) 26:4033-4045. doi:10.1091/mbc.E15-06-0397

72. Gómez-Llobregat J, Buceta J, Reigada R. Interplay of cytoskeletal activity and lipid phase stability in dynamic protein recruitment and clustering. Sci Rep (2013) 3:2608. doi:10.1038/srep02608

73. Koppel DE, Sheetz MP, Schindler M. Matrix control of protein diffusion in biological membranes. Proc Natl Acad Sci (1981) 78:3576-3580. doi:10.1073/pnas.78.6.3576 
74. Lenne P-F, Wawrezinieck L, Conchonaud F, Wurtz O, Boned A, Guo X-J, Rigneault H, He H-T, Marguet D. Dynamic molecular confinement in the plasma membrane by microdomains and the cytoskeleton meshwork. EMBO $J$ (2006) 25:3245-3256. doi:10.1038/sj.emboj.7601214

75. Javanainen M, Martinez-Seara H, Metzler R, Vattulainen I. Diffusion of Integral Membrane Proteins in Protein-Rich Membranes. J Phys Chem Lett (2017) 8:4308-4313. doi:10.1021/acs.jpclett.7b01758

76. Zhang M, Moran M, Round J, Low TA, Patel VP, Tomassian T, Hernandez JD, Miceli MC. CD45 Signals outside of Lipid Rafts to Promote ERK Activation, Synaptic Raft Clustering, and IL-2 Production. J Immunol (2005) 174:1479-1490. doi:10.4049/jimmunol.174.3.1479

77. Mielenz D, Vettermann C, Hampel M, Lang C, Avramidou A, Karas M, Jäck H-M. Lipid Rafts Associate with Intracellular B Cell Receptors and Exhibit a B Cell Stage-Specific Protein Composition. J Immunol (2005) 174:3508-3517. doi:10.4049/jimmunol.174.6.3508

78. Gupta N, Wollscheid B, Watts JD, Scheer B, Aebersold R, DeFranco AL. Quantitative proteomic analysis of $\mathrm{B}$ cell lipid rafts reveals that ezrin regulates antigen receptor-mediated lipid raft dynamics. Nat Immunol (2006) 7:625-633. doi:10.1038/ni1337

79. Kabouridis PS, Jury EC. Lipid rafts and T-lymphocyte function: Implications for autoimmunity. FEBS Lett (2008) 582:3711-3718. doi:10.1016/j.febslet.2008.10.006

80. Bakker TR, Piperi C, Davies EA. Comparison of CD22 binding to native CD45 and synthetic oligosaccharide. Eur $J$ Immunol (2002) 32:1924-1932. doi:10.1002/15214141(200207)32:7<1924::AID-IMMU1924>3.0.CO;2-N

81. Cairo CW, Das R, Albohy A, Baca QJ, Pradhan D, Morrow JS, Coombs D, Golan DE. Dynamic Regulation of CD45 Lateral Mobility by the Spectrin-Ankyrin Cytoskeleton of T Cells. J Biol Chem (2010) 285:11392-11401. doi:https://doi.org/10.1074/jbc.M109.075648

82. Pradhan D, Morrow JS. The Spectrin-Ankyrin Skeleton Controls CD45 Surface Display and Interleukin-2 Production. Immunity (2002) 17:303-315. doi:10.1016/S1074-7613(02)003965

83. Lokeshwar VB, Bourguignon LY. Tyrosine phosphatase activity of lymphoma CD45 (GP180) is regulated by a direct interaction with the cytoskeleton. J Biol Chem (1992) 267:21551-21557. doi:10.1016/S0021-9258(19)36645-1

84. Collins BE, Blixt O, Bovin NV, Danzer C-P, Chui D, Marth JD, Nitschke L, Paulson JC. Constitutively unmasked CD22 on B cells of ST6Gal I knockout mice: novel sialoside probe for murine CD22. Glycobiology (2002) 12:563-571. doi:10.1093/glycob/cwf067

85. Wasim L, Buhari FHM, Yoganathan M, Sicard T, Ereño-Orbea J, Julien J-P, Treanor B. NLinked Glycosylation Regulates CD22 Organization and Function. Front Immunol (2019) 10:699. doi:10.3389/fimmu.2019.00699 
86. Gadhoum SZ, Sackstein R. CD15 expression in human myeloid cell differentiation is regulated by sialidase activity. Nat Chem Biol (2008) 4:751-757. doi:10.1038/nchembio.116

87. Luzina IG, Lillehoj EP, Lockatell VK, Hyun SW, Lugkey KN, Imamura A, Ishida H, Cairo CW, Atamas SP, Goldblum SE. Therapeutic Effect of Neuraminidase-1-Selective Inhibition in Mouse Models of Bleomycin-Induced Pulmonary Inflammation and Fibrosis. J Pharmacol Exp Ther (2020) doi:10.1124/jpet.120.000223

88. Roggentin P, Kleineidam RG, Schauer R. Diversity in the properties of two sialidase isoenzymes produced by Clostridium perfringens spp. Biol Chem HOPPE SEYLER (1995) 376:569-569.

89. Wang Y, Yamaguchi K, Shimada Y, Zhao XJ, Miyagi T. Site-directed mutagenesis of human membrane-associated ganglioside sialidase - Identification of amino-acid residues contributing to substrate specificity. Eur J Biochem (2001) 268:2201-2208.

90. Simons K, Toomre D. Lipid rafts and signal transduction. Nat Rev Mol Cell Biol (2000) 1:3139. doi:10.1038/35036052 